\title{
HARM TO OTHERS FROM ALCOHOL: THE ROLE OF SOCIO-CULTURAL VARIABLES
}

\begin{abstract}
Ramón Florenzanoํㅡㄹ Gabriela Huepe ${ }^{2}$, Michelle Barr ${ }^{1}$
Abstract: This paper describes the changes in alcohol research, from a traditional individual focus on individual bodily and mental effects, to a broader focus on harm to others. This shift has coincided with broader sequential definitions of the progression from normal through harmful alcohol dependence, both in the specialized epidemiological and also in the newer classificatory systems (DSM 5 and CIE 11 draft). After presenting updated global, regional and chilean data, an international collaborative Project (Alcohol Harm to Others, ATOH) is described, with the participating institutions: the local study and the chilean components of the research team, the conceptual framework of harm to others (families, children, women; neighbors, friends, co-workers; society at large). Ethical aspects and institutional approval are presented and the principal results outlined: socio-demographic data (with special focus on the role of gender, socio-economic level and religiosity/spirituality). The data is presented for the chilean sample, with examples from other participating countries. The complexity of the link between alcohol harm to others and religious and spiritual factors is studied comparing data from several of the participating countries, and the impact upon vulnerable populations, especially women and children. The discussion reviews some of the confounding and intervening factors that could influence the results. The conclusion about prevention and policy development closes the paper.
\end{abstract}

Key words: alcohol epidemiology, harm to others, socio-cultural factors

Daño a otros por causa del alcohol: la contribución de las variables socioculturales

Resumen: Este artículo describe los cambios en investigación sobre el abuso de alcohol, desde un enfoque tradicional sobre los efectos corporales y mentales en el individuo, a un enfoque amplio sobre el dańo a otros. Este cambio ha coincidido con definiciones secuenciales más amplias de la progresión desde el estado normal a la dependencia dañina al alcohol, ambas en la especialidad de la epidemiología y también en los nuevos sistemas de clasificación (DSM 5 y propuesta de CIE 11). Después de presentar datos actualizados globales, regionales y chilenos, se describe un proyecto internacional colaborativo (Daño a Otros por Causa del Alcohol, ATOH) con las instituciones participantes: el estudio local y los componentes chilenos del equipo de investigación, la estructura conceptual de dańo a otros (familias, nińos, mujeres; vecinos, amigos, compañeros de trabajo; la sociedad en general). Se presenta la aprobación institucional y aspectos éticos, así como se delinean los principales resultados: datos sociodemográficos (con enfoque especial en el rol de género, nivel socioeconómico y espiritualidad/religiosidad). Se presentan los datos de la muestra chilena, con ejemplos de otros países participantes. Se estudia la complejidad del vínculo entre el daño por alcohol a otros y factores religiosos y espirituales, comparando datos de varios de los países participantes, y el impacto sobre poblaciones vulnerables, especialmente mujeres y nińos. La discusión revisa algunos de los factores de confusión y de intervención que podrían influenciar los resultados. Se cierra el artículo con conclusiones sobre prevención y desarrollo de normativas.

Palabras clave: epidemiología del abuso de alcohol, daño a otros, factores socioculturales

Dano a outros causado pelo álcool: o papel das variáveis socioculturais

Resumo: Este artigo descreve as alteraçôes na pesquisa do álcool, a partir de um foco individual tradicional sobre os efeitos orgânicos e mentais individuais, para um foco mais amplo sobre danos a outros. Essa mudança coincidiu com mais amplas definiçóes sequenciais da progressão do normal através de dependência de álcool prejudiciais, tanto na epidemiologia especializada como nos sistemas classificatórios mais recentes (DSM 5 e CIE 11 minuta). Depois de apresentar dados atualizados globais, regionais e chileno, um projeto internacional colaborativo (Alcohol Harm to Others, ATOH) é descrito, com as instituiçóes participantes: o estudo local e os componentes chilenos da equipe de pesquisa, o quadro conceitual do dano a outrem ( famílias, crianças, mulheres, vizinhos, amigos, colegas de trabalho, e sociedade em geral). Aspectos éticos e aprovação institucional são apresentados e os principais resultados delineados: dados sócio-demográficos (com especial destaque para o papel do sexo, nível socioeconômico e espiritualidade / religiosidade). Os dados são apresentados para a amostra chilena, com exemplos de outros países participantes. A complexidade da relação entre efeitos nocivos do álcool para os outros e fatores religiosos e espirituais é estudada comparando os dados de vários dos países participantes, bem como o impacto sobre populaçóes vulneráveis, especialmente mulheres e crianças. A discussão revê alguns dos fatores de confusão e intervenientes que poderiam influenciar os resultados. A conclusão sobre a prevenção e desenvolvimento de políticas define o papel.

Palavras-chave: epidemiologia do álcool, dano a outros, fatores socioculturais

\footnotetext{
${ }^{1}$ Universidad del Desarrollo, Chile

Correspondence: rflorenzano@gmail.com

${ }^{2}$ Universidad de Chile, Chile
} 


\section{Introduction and definitions}

Alcohol consumption has been a focus of global, regional and chilean concern given increasing evidence that its harmful use affects health. The 2010 World Health Assembly formulated a new global strategy to reduce the harmful use of alcohol(1) and the World Report on Alcohol and Health(2) presented detailed data about the different patterns of consumption in different continents. In the strategy document, one of the new elements was the advice to increase research in the harm that drinking inflicts to others, This represents a change of focus from the traditional studies and interventions centered on individual alcohol problems towards the study of how drinking harms others. In 2013, a joint initiative was launched by the World Health Organization and Thai Health International, with the participation of seven countries (Thailand, Vietnam, Lao SPR, Sri Lanka, India, Nigeria and Chile), with the object of measuring the impact of drinking in "The Harm to Others from Drinking" master procotol(3). In Chile this initiative was led by the Faculties of Government and Psychology of the Universidad del Desarrollo, with participation of the Facultad de Medicina of the Universities of Chile and Los Andes, and the National Service for Prevention of Alcohol and Drug Addiction (SENDA).

Chile is a middle income country that produces and exports wine. The national identity has been for a long time tied to drinking, and there is a lack of awareness that drinking can harm the environment, especially the most vulnerable: women, children and families. Most of the chilean research so far has centered in the effects of alcohol in individuals or in measuring the societal costs of drinking. However, a recent study found that $11,9 \%$ of cases seen in a psychiatric unit in Metropolitan Santiago had an alcoholic parent or relative. This increased to $42,9 \%$ of patients in the Alcohol and Substance Abuse Unit(4).

In Chile the main beverage of consumption has traditionally been wine, but beer and liquor use has been on the rise in the last two decades. The average per capita consumption of alcoholic beverages is 8,6 liters, with a gender ratio of 2,4 : average consumption for males is $16,7 \mathrm{lt}$. and for females is 8,2 . The percentage of current drinkers has decreased in the last few years: in the 9th $\mathrm{Na}$ tional Survey for the general population in 2010, $40,5 \%$ of the population drank alcohol in the last month, in comparison to 59,2 in the 2002 survey(5).

The field called "transcultural" psychiatry, analyzes how specific cultural variables included adscription to major religions, paying high attention to individual and collective meaning of prayer, and highlighting those features connected to spiritual practice, which are also relevant to psychiatry. Alarcón(6) has reviewed the links between this approach and their relationship with cultural issues.

Spirituality and religiosity are among the cultural variables that influence the frequency and severity of alcohol second-hand effects. Spirituality is one of the challenges that the present global situation presents: SR issues have been seen as protection from social ills, but fundamentalist positions can be seen as threats to world stability. A recent Lancet Editorial stated "At a time in human history when people of faith are being executed for their words and beliefs, when religion is co-opted as justification for terrorism, and when hate speech from politicians in large democracies inflames conditions for violence, this brief but sometimes anguished exchange, which turned into a philosophical investigation into faith and freedom, perhaps revealed the limits of and, more importantly, the opportunities for reason, evidence, and argument in all cultures" (7).

The objective of this paper is to describe some of the findings of the first phase of this study, with special focus on the cultural aspects of the damage to third persons by drinking.

\section{Methodology of the study}

\section{The survey}

A nationally representative survey of the chilean population was conducted between May and July of 2013. Through face-to-face application, data on the impact of alcohol on people other than the drinker was collected. Information on sociodemographic factors, and religious adscription and beliefs was also gathered. The questionnaire 
was applied to individuals aged 18 an over. It was prepared by the $\mathrm{H} 2 \mathrm{O} \mathrm{WHO} /$ Thai International research project team and translated into Spanish. As the WHO translation protocols require, the Spanish questionnaire was back-translated to check meaning.

The instrument was applied to a representative sample (using a multi-etapic probabilistic method) of a total population of 12,291,000 inhabitants of 14 regions of Chile (CASEN, 2011). The response rate was of $71,8 \%$, leading to a final recollection of 1,500 complete interviews.

The questionnaire took on average 45 minutes to administer. An external firm, in formal collaboration with Universidad del Desarrollo, applied the surveys. The surveyors received a formal specific training and were supervised by an experienced fieldwork director, according to the guidelines of the $\mathrm{WHO} /$ Thai Health project.

\section{Ethical aspects and institutional approval}

Approval for this study was obtained from the Ethical Review Committee of the WHO for the master protocol and by the Research Ethics Board of the Universidad del Desarrollo for the Chile project.

\section{Results}

The results of a sample of 1,500 responders to the national survey have been reported elsewhere ${ }^{\beta}$ ). They demonstrate that about one third of the sample was negatively affected by drinking of others: $16,5 \%$ were somewhat affected and $13,5 \%$ were very much affected. The main effects were due to verbal maltreatment $(21,1 \%)$, being bullied or molested in a private place $(14,3 \%)$, a drunken driver the person's vehicle $(13,8 \%)$, problems with neighbours $(9,8 \%)$, family or marital problems $(8,2 \%)$, property damage's $(6,3 \%)$, destruction of clothes or belongings $(4,4 \%)$ or traffic accident produced by a drunken driver $(3,3 \%)$.

Women were more affected than men: $17,8 \%$ of women respondents were affected vs $10,7 \%$ or men. Drinking by an immediate family member, other than spouse or partner, affected more men $(15 \%)$ than females $(6,1 \%)$. Drinking by other household members affected also more men $(4,9 \%)$ than women (3\%). The opposite was true for spouse or partner $(2,7 \%$ of women were affected in comparison to $0,7 \%$ of men).

The overall results show that the percentage affected by drinkers is $34,3 \%$ of the population: one out of three Chileans are damaged by other's drinking. This percentage is very close if we compare drinking by family and friends $(37 \%)$ and by strangers $(34,1 \%)$.

When we analyze the socio-economic level of the sample (Table 3), the perception of harm from alcohol is more negative with decreasing income level, which is statistically significant $(\mathrm{X} 2=$ $56.403,12 \mathrm{~g}, 1, \mathrm{p}=0.0001$ ), indicating that the variable is linked to the perception of harm due to alcohol consumption in third. In all SES the neutral effect predominated. In the $\mathrm{ABC} 1$ group, the effect of consumption is perceived more positively or neutral, while in groups $\mathrm{D}$ and $\mathrm{E}$ is perceived as more negative.

\section{Role of Spirituality / religiosity}

The religious self-adscription of the sample was close to what is found in chilean population as a whole: $56,6 \%$ were catholics, $13,3 \%$ other Christian, 1,3 belonged to other religions (Muslims, Jews, Jehova Witness), 3,2\% agnostic, 5,7\% atheist, $20,4 \%$ did not have any preference. Table 1 shows that there were statistically significant differences in the perceived effects of alcohol: $48,5 \%$ of non catholic Christians felt this effect was negative, in comparison to $33,5 \%$ of Catholics and $25,2 \%$ of agnostic or atheists. Table 2 shows that the overall effect of alcohol in the life of the respondents was deemed somewhat or very negative by $42,9 \%$ of church attenders, and somewhat of very positive by $12,2 \%$ of non attenders (in comparison to $30,5 \%$ and $9,6 \%$ ). Those differences were significant $(\mathrm{p}=0,001)$.

\section{Conclusions}

This paper focuses upon the contextual variables that influences the effects of drinking in the surrounding human environment of people that consume alcohol. This effect increases in heavy or excessive drinkers, but also varies depending on 
the gender, socio-economic status, educational level, and religious or spiritual beliefs. The ATOH international comparisons are beginning to throw light on these different contextual variables, that influence the global mental health, a subject that has become popular in the last decade, opening the possibility of interventions based in decreasing national or ethnic inequities.

Findings that at higher income, drinking alcohol is perceived as positive or neutral is interesting to preventive and public policy plans. Industry messages focus on the positive effects of alcohol on their enjoyment or the enjoyment of leisure time oriented to people that have more financial capacity and leisure time. Alcohol propaganda highlights this. In the lower income groups, the effect of drinking of others is perceived more negative, and the effects of excessive drinking may be more deleterious for consumers not only themselves, but their families and their environment. In another, qualitative, study (in press), physical and psychological violence against women and children were one ot the main consequences.

The per capita consumption of alcohol in the countries that participate in the ATOH study is related to the religious beliefs of their populations: if we compare tables 1 and 2, the two countries with the highest per capita consumption, are the two with a majority of Christian population: $\mathrm{Ni}$ geria in the first place, followed by Chile. Buddhist countries, such as Thailand and Lao PDR, comes next, with India, with sizeable Hindu and Muslim populations, in the last place.

Gender has been studied in the project that anteceded ATOH: in GENACIS (Gender and Alcohol Consumption International Study), the gap between masculine and feminine intake of alcohol has been shown to decrease, as the process of modernization advances, with progressive equality between both genders. In the chilean sample of this study, women have a more negative perception of alcohol intake by relatives or other known drinkers, especially when they are partners or close relatives. More educated people, with university or post graduate studies have a more positive perception of drinker, versus less educated groups, especially those with incomplete secondary education.
With regards to religious self-adscription, Catholics have a more positive view of drinking, with other Christians having the most negative one: $33,5 \%$ of Catholics have a negative perception of the effects of drinking by people living with them (relatives or known persons), in comparison to $48 \%$ of other Christians. In Chile, abstinence of alcohol has been since the appearance of reformed churches in the country, by the turn of the XX Century, a key tenet of appeal to convert to them. The only group that has a more positive perception of effects of drinking among others than Catholics are non-believers $(74,8 \%$ vs $67,4 \%)$.

There is a difference between self-adscription to a religion and observance of their moral practices: in Chile Catholicism has been the religion of the majority of the population since the Spanish conquest, and was the official religion of the Chilean state until 1929. Many people say that they are catholics but do not practice or attend their churches but in some important social events, as marriages or funerals. When observance is taken into account (Table 4), the amount of people that have negative views of drinking of others increases ( $42,9 \%$ vs $30,5 \%$ of non belongers). The sub-group that appears to be protected is the one formed by active religious practitioners. 
Tables

Table 1. Patterns and levels of consumption for men and for women, in 7 countries participating in ATOH collaborative study, 2013-2015.

\begin{tabular}{|c|c|c|c|c|c|c|c|c|c|}
\hline & \multirow{2}{*}{$\begin{array}{l}\text { Adult pc } \\
\text { consump- } \\
\text { tion }\end{array}$} & \multirow{2}{*}{$\begin{array}{l}M \text { a i n } \\
\text { beverage }\end{array}$} & \multicolumn{3}{|c|}{ Consumption per drinker } & \multicolumn{4}{|c|}{ Current drinkers (\%) } \\
\hline & & & Male & Female & $\begin{array}{l}\text { Gender } \\
\text { ratio }\end{array}$ & All & Male & Female & $\begin{array}{l}\text { Gender } \\
\text { ratio }\end{array}$ \\
\hline Nigeria & $\underline{12.3}$ & Beer & $\underline{36.9}$ & $\underline{23.0}$ & 1.6 & 38.3 & 50.6 & 26.3 & 1.9 \\
\hline Chile & 8.6 & Wine & 16.7 & 8.2 & 2.0 & 67.6 & 65.3 & 60.2 & 1.1 \\
\hline Thailand & 7.1 & Spirits & 29.1 & 6.2 & $\underline{4.7}$ & 29.6 & 48.2 & 12.5 & 3.9 \\
\hline Laos & 6.7 & Spirits & 20.8 & 9.1 & 2.3 & 39.2 & 55.6 & 23.5 & 2.4 \\
\hline Vietnam & 3.8 & Beer & 16.1 & 11.6 & 1.4 & 24.1 & 47.4 & 1.3 & $\underline{36.5}$ \\
\hline India & 2.6 & Spirits & 23.9 & 10.4 & 2.3 & 9.9 & 20.0 & 3.0 & 6.7 \\
\hline Sri Lanka & 0.8 & Spirits & 9.3 & 6.9 & 1.3 & 8.8 & 17.0 & 0.9 & 18.9 \\
\hline
\end{tabular}

Consumption in litres of pure alcohol per annum; pc = per capita; Underlined: highest; italic: lowest Source: WHO. Global Status Report on Alcohol and Health. Geneva: World Health Organization; 2011.

Table 2: Religious adscription by country.

\begin{tabular}{|l|l|l|l|l|l|l|}
\hline Country of survey & Religious adscription & & & & & \\
\hline & Any Christian & Buddhist & Muslim & Other religions & Agnostic/atheist & No preference \\
\hline Sri Lanka $(\mathrm{n}=2475)$ & $7,4 \%$ & $66,5 \%$ & $5,4 \%$ & $0 \%$ & $0 \%$ & $0 \%$ \\
\hline Nigeria In=2257) & $92 \%$ & $0 \%$ & $1,6 \%$ & $6,3 \%$ & $0 \%$ & $0 \%$ \\
\hline India $(\mathrm{n}=3399)$ & $2,1 \%$ & $0 \%$ & $6,9 \%$ & $91,9 \%$ & $0 \%$ & $0 \%$ \\
\hline Thailand $(1695)$ & $1,1 \%$ & $93,9 \%$ & $5 \%$ & $0 \%$ & $0 \%$ & $0 \%$ \\
\hline Chile $(\mathrm{n}=1500)$ & $67,5 \%$ & $0 \%$ & $0,2 \%$ & $0,9 \%$ & $5,1 \%$ & $20,7 \%$ \\
\hline Vietnam $(\mathrm{n}=1501)$ & $11,7 \%$ & $0 \%$ & $25,8 \%$ & $0 \%$ & $0,2 \%$ & $62,4 \%$ \\
\hline LAO PDR $(1257)$ & $0,2 \%$ & $94,5 \%$ & $5,3 \%$ & $0 \%$ & $0 \%$ & $0,1 \%$ \\
\hline & & & & & & \\
\hline TOTAL $(\mathrm{N}=14011)$ & $25,1 \%$ & $25,7 \%$ & $34,4 \%$ & $27,4 \%$ & $0,8 \%$ & $8,8 \%$ \\
\hline
\end{tabular}


Harm to others from alcohol: the role of socio-cultural variables - Ramon Florenzano, Gabriela Huepe, Michelle Barr

Table 3: Socio-demographic characteristics and perception of the general effect $(\$)$ of alcohol consumption by third parties in the last 12 months. Population survey in Chile, 2013.

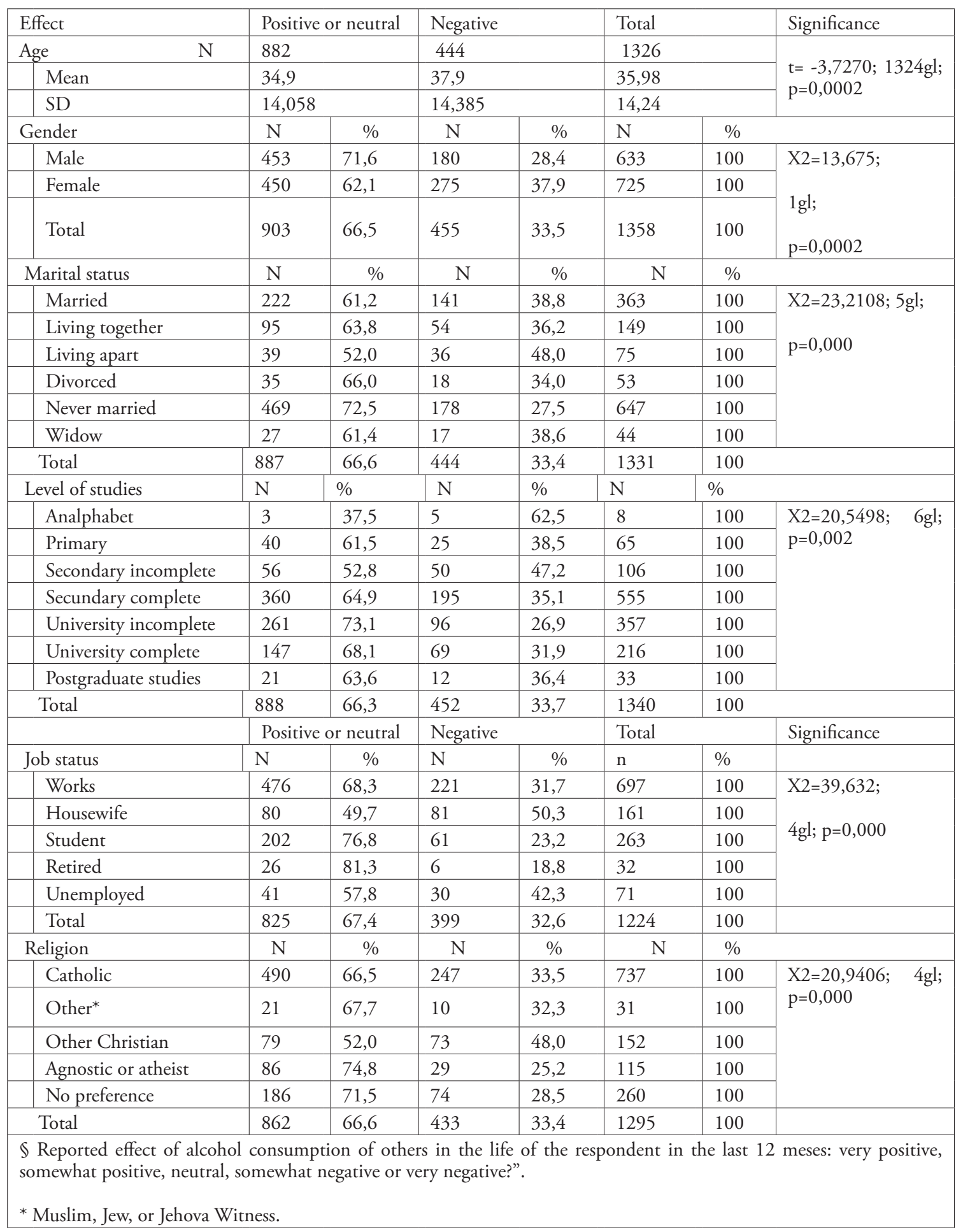


Table 4: Religious attendance and effects of drinking in third persons, Chile, 2013.

\begin{tabular}{|l|l|l|l|l|l|l|}
\hline & \multicolumn{2}{|l|}{ Overall effect of others' drinking on your life } & \multicolumn{2}{l|}{ Total } \\
\hline Church belonging & Very positive & Somewhat positive & Neutral & Somewhat negative & \multicolumn{2}{|l|}{ Very negative } \\
\hline No & 35 & 86 & 556 & 174 & 123 & 974 \\
\hline & $3.60 \%$ & $8.80 \%$ & $57.10 \%$ & $17.90 \%$ & $12.60 \%$ & $100.00 \%$ \\
\hline Yes & 13 & 20 & 164 & 75 & 73 & 345 \\
\hline Total & $3.80 \%$ & $5.80 \%$ & $47.50 \%$ & $21.70 \%$ & $21.20 \%$ & $100.00 \%$ \\
\hline & 48 & 106 & 720 & 249 & 196 & 1319 \\
\hline
\end{tabular}

$\mathrm{X} 2=21,695 ; 4 \mathrm{gl} ; \mathrm{p}=0,0001$

Table 5: Religious adscription by country.

\begin{tabular}{|l|l|l|l|l|l|l|}
\hline Country of survey & $\begin{array}{l}\text { R e l i g i o u s } \\
\text { adscription }\end{array}$ & & & & & \\
\hline & Any Christian & Buddhist & Muslim & Other religions & Agnostic/atheist & No preference \\
\hline Sri Lanka (n=2475) & $7,4 \%$ & $66,5 \%$ & $5,4 \%$ & $0 \%$ & $0 \%$ & $0 \%$ \\
\hline Nigeria In=2257) & $92 \%$ & $0 \%$ & $1,6 \%$ & $6,3 \%$ & $0 \%$ & $0 \%$ \\
\hline India (n=3399) & $2,1 \%$ & $0 \%$ & $6,9 \%$ & $91,9 \%$ & $0 \%$ & $0 \%$ \\
\hline Thailand $(1695)$ & $1,1 \%$ & $93,9 \%$ & $5 \%$ & $0 \%$ & $0 \%$ & $0 \%$ \\
\hline Chile $(\mathrm{n}=1500)$ & $67,5 \%$ & $0 \%$ & $0,2 \%$ & $0,9 \%$ & $5,1 \%$ & $20,7 \%$ \\
\hline Vietnam $(\mathrm{n}=1501)$ & $11,7 \%$ & $0 \%$ & $25,8 \%$ & $0 \%$ & $0,2 \%$ & $62,4 \%$ \\
\hline LAO PDR (1257) & $0,2 \%$ & $94,5 \%$ & $5,3 \%$ & $0 \%$ & $0 \%$ & $0,1 \%$ \\
\hline & & & & & & \\
\hline Total (N=14011) & $25,1 \%$ & $25,7 \%$ & $34,4 \%$ & $27,4 \%$ & $0,8 \%$ & $8,8 \%$ \\
\hline
\end{tabular}


Harm to others from alcohol: the role of socio-cultural variables - Ramon Florenzano, Gabriela Huepe, Michelle Barr

Table 6: Religious adscription and perceived effects of drinking in the last 12 months, intercountry sample ( $\mathrm{n}=13437), 2013-2015$.

\begin{tabular}{|l|l|l|l|l|l|l|l|l|l|}
\hline Religious preference & $\begin{array}{l}\text { Any } \\
\text { Christian }\end{array}$ & Hindu & Buddhist & Muslim & Other religion & Agnostic & Atheist & No preference & Total \\
\hline Very positive & 469 & 275 & 240 & 39 & 27 & 2 & 5 & 16 \\
\hline & $11 \%$ & $7.70 \%$ & $5.00 \%$ & $8.10 \%$ & $14.40 \%$ & $4.50 \%$ & $7.00 \%$ & $1.40 \%$ \\
\hline Somewhat positive & 628 & 177 & 370 & 29 & 44 & 6 & 12 & 53 \\
\hline & $15 \%$ & $5.00 \%$ & $7.70 \%$ & $6.10 \%$ & $23.00 \%$ & $13.60 \%$ & $16.90 \%$ & $4.50 \%$ \\
\hline Neutral & 1805 & 911 & 2690 & 145 & 86 & 22 & 39 & 634 \\
\hline & $42 \%$ & $25.50 \%$ & $56.00 \%$ & $30.30 \%$ & $44.00 \%$ & $50.00 \%$ & $54.90 \%$ & $53.90 \%$ \\
\hline Somewhat negative & 962 & 706 & 1132 & 122 & 36 & 11 & 12 & 392 \\
\hline & $23 \%$ & $19.80 \%$ & $23.60 \%$ & $25.50 \%$ & $17.00 \%$ & $25.00 \%$ & $16.90 \%$ & $33.30 \%$ \\
\hline Very negative & 407 & 1499 & 373 & 144 & 6 & 3 & 3 & 82 \\
\hline & $10 \%$ & $42.00 \%$ & $7.80 \%$ & $30.10 \%$ & $3.00 \%$ & $6.80 \%$ & $4.20 \%$ & $7.00 \%$ \\
\hline Total & 4271 & 3568 & 4805 & 479 & 188 & 44 & 71 & 1177 \\
\hline
\end{tabular}

Chi-cuadrado de Pearson= 3201,12;44 gl; p=0,0001

Figure 1: General perception of the effects of alcohol perception by third parties $(n=1295)$ and religious self-adscription Likert scale and percentages

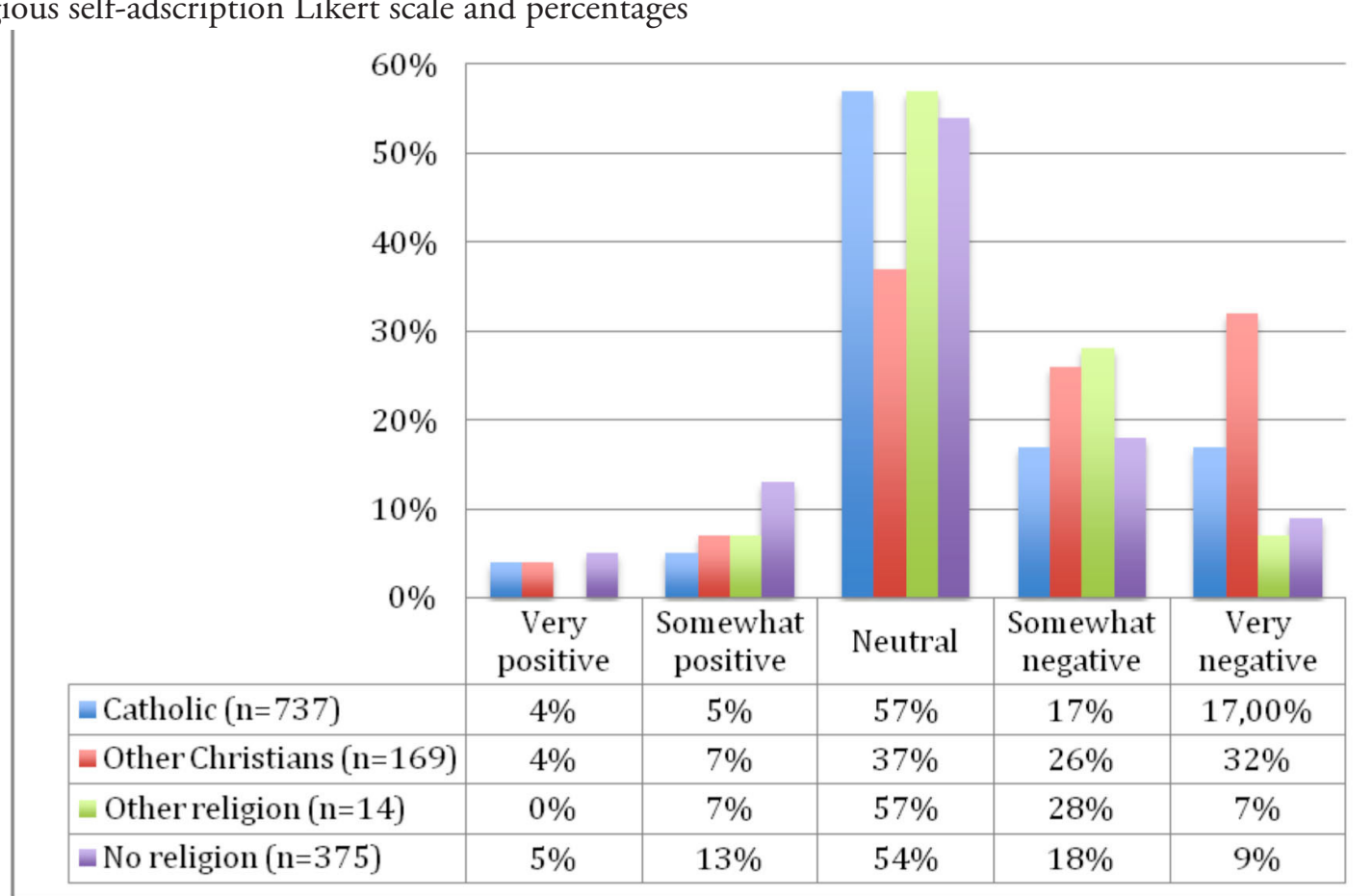

$\mathrm{X} 2=61.966 ; 32 \mathrm{gl} ; \mathrm{p}=0,001$ 


\section{References}

1. World Health Organization. Resolution WHA63.13, 2010.

2. World Health Organization. World Report on Alcohol and Health 2014. Geneva, Switzerland.

3. World Health Organization/Thai Health International. The Harm to Others from Drinking Master Protocol. Mimeo.

4. Florenzano R, Hernández C, Venegas L, Larraín C, Godoy JP, Sieverson C. Alcoholismo en la Familia y Salud Mental en hijos adultos. Valdivia, Chile: Poster presentado en $168 .^{\circ}$ Congreso de la Sociedad de Neurología, Psiquiatría y Neurocirugía.

5. SENDA. Noveno Estudio de Consumo de Drogas en la Población General 2010. SENDA, Santiago de Chile, 2011.

6. Alarcón R. Global Mental Health and systems of diagnostic classification: clinical and cultural perspectives. Acta Bioethica 2016; 22(1): 15-25.

7. Editorial Comment: Offline: When Science Meets Faith. Lancet 2016; 387.

8. Florenzano R, Guzmán E, Sieverson C, Castillo-Carniglia, A, Gérnandez MA, Echeverría A. Daño a Terceros Producido por el Alcohol: resultados de un estudio poblacional en Chile. Revista Médica de Chile, 2015; 143: 1242-1251.

Received: March 13, 2016

Accepted: March 29, 2016 